\title{
The potential ethnomedicine plant of Impatiens balsamina leaves from Pontianak, West Kalimantan, Indonesia for wound healing
}

\author{
HARIYANTO IH", INARAH FAJRIATY ${ }^{\bullet \bullet}$, TANTO WIJAYA, MUHAMMAD HAFIZH \\ Department of Pharmacy, Faculty of Medicine, Universitas Tanjungpura. Jl. Prof. Hadari Nawawi, Pontianak 78121, West Kalimantan, Indonesia. \\ Tel.: +62-561-765342, 583865, 732500, Fax.: +62-561-765342, `email: hariyanto.ishak@gmail.com, `"inarah.fajriaty@yahoo.com,
}

Manuscript received: 12 October 2017. Revision accepted: 28 February 2018.

\begin{abstract}
Hariyanto IH, Fajriaty I, Wijaya T, Hafizh M. 2018. The potential ethnomedicine plant of Impatiens balsamina leaves from Pontianak, West Kalimantan, Indonesia for wound healing. Nusantara Bioscience 10: 58-64. Pacar air or garden balsam (Impatiens balsamina L.) is a herb plant that grows wildly in high humidity areas. The leaves of I. balsamina are used by the people in Bengkulu, Indonesia, as herbal medicine to treat wounds. I. balsamina grows abundantly in West Borneo due to the proper conditions. This study aimed to determine the wound healing activity of $I$. balsamina as an ethnomedicine plant and standardize its extract. The leaves of $I$. balsamina was macerated with $96 \%$ ethanol. The extraction yield was $20.3 \%$, the solubility of the extract in water and ethanol was $15.77 \%$ and $41.41 \%$, respectively, the drying rate was $23.02 \%$, and the extracted density was $0.8136 \mathrm{~g} / \mathrm{mL}$. The extract of I. balsamina contained polyphenols, flavonoids, saponins, tannins, quinones, steroids, and terpenoids based on the phytochemical screening. Anatomical and histological pathology tests showed that the leaves extract had the potential to heal the external wound.
\end{abstract}

Keywords: Ethnomedicine, Impatiens balsamina, wound healing

\section{INTRODUCTION}

Pacar air or garden balsam (Impatiens balsamina L.) is a plant originating from South and Southeast Asia. It has white, red, purple, or pink flowers. The height of this plant can reach up to one meter with thick but not woody stems and serrated-edge leaves. Pacar air plants are usually grown as ornamental plants and grow well in a place with enough water and sunlight (Depkes RI 1994). Pontianak, the capital city of West Borneo, has both high air and soil humidity, high rainfall and long sunlight exposure which are a perfect condition for the plant growth. Indonesian people including those in Bengkulu, have used the fresh I. balsamina as medicine for treating wound and swelling (Adfa 2008).

The leaves of I. balsamina Linn. have been known to contain phytochemical compounds such as coumarins, quinones, tannins, flavonoids, saponins, scopoletin, steroids and triterpenoids (Adfa 2008). Saponin compounds stimulating the collagen growth during the healing process, have the effect of relieving pain and stimulating cell proliferation and migration (Depkes RI 1994; Kang et al. 2013). Flavonoids have water-soluble properties and function as antimicrobial, antiviral, and immunomodulator (Adfa 2006). Inhibition of bacterial activity is one of the factors that increase the activity of wound healing. Phytochemical screening of I. balsamina Linn leaves showed that glycosides and phenolics compounds are present in the leaves of these plants (Oku and Ishiguro 2011). All of these chemical components play an important role in the antimicrobial activity. Thus, it is also important in wound healing process.

Wound healing is a complex and dynamic process involving both biocellular and biochemical activities (Vogt
2006). Povidone-iodine is clinically used for wound healing treatment because of its antimicrobial effect, and ability to create a humid environment. However, the use of $10 \%$ povidone-iodine has an inhibitory effect on fibroblast growth in cell culture in vitro (Balin and Pratt 2002; Vogt 2006). Empirically, the leaves of I. balsamina used to treat the wound is approximately $15-30 \mathrm{~g}$. It is necessary to find the activity of ethanol extract of I. balsamina leaves in the wound healing process that does not cause the inhibition of fibroblast growth.

\section{MATERIALS AND METHODS}

\section{Study area}

Samples of I. balsamina Linn. leaves were taken at Jalan Alianyang, Kelurahan Sei. Bangkong, Kecamatan Pontianak Barat, Pontianak, West Kalimantan, Indonesia.

\section{Procedures}

Phytochemical Screening

Phytochemical screening aimed to determine the chemical compounds contained in the extract. All screening test was conducted with three times repetitions. The screening test procedure is as described below:

Alkaloid test. The extracts were mixed with an ammoniac-chloroform solution in test tubes. The mixture was shaken and then filtered. Next, the filtrate is added to 0.5-1 mL of $2 \mathrm{~N}$ sulfuric acid and shaken until two layers are formed. The acid layer (top) was transferred into two test tubes. The solution from the first test tube was added with two drops of Meyer reagent. Meanwhile, the solution in the second test tube was mixed with two drops of 
Dragendrorf reagent. The presence of an alkaloid compound is characterized by the formation of white precipitate in the first test tube and the emergence of a reddish-brown precipitate in the second reaction tube (Kristanti et al. 2008).

Polyphenol test. The leaves extract was dissolved in ethanol, then added with three drops of $1 \% \mathrm{FeCl}_{3}$ reagent. Formation of green, blue or purple color of the solution indicates a phenol compound (Harborne 1998)

Tannin test. The leaves extract was dissolved in ethanol, then added with three drops of $5 \% \mathrm{FeCl}_{3}$ reagent. When the solution turns dark blue or dark green, it indicates the presence of tannin (Robinson 1983)

Flavonoid test. $1 \mathrm{ml}$ leaves extract was mixed with 1 gram of magnesium powder, and $1 \mathrm{ml}$ concentrated $\mathrm{HCl}$ solution. The changing of the solution to red indicates the presence of flavonoids (Robinson 1983)

Quinone test. The leaves extract was dissolved in aquadest, then filtered. The filtrate was added with 5 drops of $5 \% \mathrm{KOH}$. It indicates the presence of quinone if the solution turns red (Depkes RI 1995).

Saponin test. $2 \mathrm{~mL}$ leaves extract was put into a test tube, then added with water and shaken strongly for 15 minutes. If the foam formed lasts for 10 minutes at $1 \mathrm{~cm}$ of high, this indicates the presence of saponin (Robinson 1983)

Steroid and triterpenoid test. The leaves extract was dissolved in $1 \mathrm{~mL}$-hexane and $1 \mathrm{~mL}$ Lieberman-Burchard reagent (Glacial $\mathrm{CH}_{3} \mathrm{COOH}$ and concentrated $\mathrm{H}_{2} \mathrm{SO}_{4}$ solution). If the solution color turns to a turquoise blue, it indicates the presence of triterpenoid compounds (Harborne 1998)

\section{Thin Layer Chromatography}

The TLC plate (silica gel 60 F254 with an area of $1 \times 7$ $\mathrm{cm})$ was activated in an oven at $105^{\circ} \mathrm{C}$ for 10 minutes. Then the ethanol extract of I. balsamina leaves was blotted onto the TLC plate using a small capillary pipe, at a distance of $1 \mathrm{~cm}$ from the bottom. Blotting was conducted 2-3 times and left to dry. The blotted plates were eluted in TLC chamber with ethyl acetate, methanol, and water with a ratio of 77: 13: 10. The distance of elution was $5 \mathrm{~cm}$. After being eluted; the plate was taken and aerated until dry. The plates were then irradiated under UV lamps with wavelengths of 254 and $366 \mathrm{~nm}$. The plate then sprayed with $10 \% \mathrm{H}_{2} \mathrm{SO}_{4}$ spotting in methanol.

\section{Extracts preparation}

The leaves were dried in a dryer cabinet and then ground by a blender machine. Samples were extracted by maceration method. I. balsamina simplicia were inserted into a glass vessel, soaked with $96 \%$ ethanol and left for 24 hours while stirred occasionally. The macerate was moved into glass bottles, then re-macerated until it became clear. The maceration results were concentrated with a rotary evaporator to get a viscous extract (Adfa 2006).

The extract was weighed and suspended in glycerin. The dosage of the extract used was based on the empirical use of the I. balsamina leaves as a treatment for the wound.

\section{Animal model and dose treatment}

This study used male Rattus norvegicus from Wistar strain as the test animal. The rat was anesthetized and hairs in the wound area were shaved. The skin was cleaned using alcohol $70 \%$. The wound was made at the center of the rat's back with a diameter of $\pm 20 \mathrm{~mm}$ and a depth of $2 \mathrm{~mm}$ using surgical scissors.

The extracts were administered every day starting from the day when the wound was made (day-0) until day-13, every morning and afternoon. The dosage of the extract was given $10.5 \mathrm{mg} /$ wound area (dose-1 group) and 21 $\mathrm{mg} /$ wound area (dose-2 group) for each rat. The untreated group was used as the normal control, the group given glycerin as the negative control, and the group gave povidone-iodine as the povidone-iodine control.

\section{Anatomical pathology observation}

Observations of anatomical pathology were conducted on day $2,4,6,8,10,12,14$ and 15 . The anatomical pathology parameters including the density of the skin, dryness of the wound, and scabs were observed (Winarsih et al. 2010).

\section{Histology preparation}

Three rats from each group were necropsied on day 7 after wound infliction for histopathological examination. The sample was prepared for histology preparations with Hematoxylin-Eosin staining and observed under a microscope. The average number of inflammatory cells and the area of collagen formation was done by counting the number of cells and measuring the area of collagen in histologic preparations under the light microscope with $400 \mathrm{x}$ magnification as much as 8 fields of view.

\section{Data analysis}

All the data were analyzed by comparing the differences between the group of control, extract, and povidone-iodine using One Way Analysis of Variance (ANOVA)

\section{RESULTS AND DISCUSSION}

\section{Characteristics of extract}

The result of the ethanol extraction of I. balsamina leaves y maceration, and standardization can be seen in Table 1 .

\section{Descriptive observation}

The descriptive observation shows that the inflammatory stage occurred on the first day of the injury, where the wound was wet, and the skin around the wound was swollen and reddish. The second stage of wound healing, the proliferation stage, occurred on day 3 in which the wound was dry and showed no inflammation. The proliferation stage in the extract group begins faster compared to that in the control group. The last stage, the maturation stage, occurred on day 4 and was stopped until the wound extinct and only scar left. Both the extract doses 
showed a shorter maturation stage compared with the other groups.

The observation of the wound area was started on day 2 after the wound infliction and was determined as the first day of the observation. The percentage of wound healing activity from day 4 until day 15 were compared with the wide area of the wound on the first day of the observation. The observation results showed that the group with the highest healing activity was group of the dose- 1 followed by the dose- 2 group. Compared to the wound of the dose- 1 group, the wound treated with dose- 2 formed hardened scabs and required a longer time to detach from the skin, thus affecting the speed of the wound healing.

Figure 4 shows the formation of scabs that began to appear on the fifth day of observation, wherein all three control groups and dose-2 group exhibited a thick scab formation, but did not in the dose-1 group. Slower scabs formation allows the wound to become smaller before eventually dried and formed a scab. Observation of the wound area and healing activity of each group was stopped when the formation of scabs on the wound occurred. The administration of the extract will not give the desired effect when applied to the wound with a scab on it because the scab prevents the absorption of the chemical compounds into the skin.

\section{Histological observation}

The histological observation results showed that the treatment of the ethanolic extract of I. balsamina leaves resulted in fewer inflammatory cells and wider collagen area compared with those of control (Figure 5).

Figure 5 shows the qualitative differences in the number of inflammatory cells and collagen extents between groups. The povidone-iodine control group (Figure 5.C) had more inflammatory cell counts and less collagen area

Table 1. Characteristic and phytochemical screening results

\begin{tabular}{lc}
\hline Parameters & Results \\
\hline Extract yield & $20.3 \%$ \\
Solubility in water $(\% \mathrm{w} / \mathrm{w})$ & $15.77 \%$ \\
Solubility in ethanol $(\% \mathrm{w} / \mathrm{w})$ & $41.41 \%$ \\
Drying rate $(\%)$ & $23.02 \%$ \\
$1 \%$ extract density $(\mathrm{g} / \mathrm{mL})$ & 0.8136 \\
Chemical compounds & \\
$\quad$ Alkaloids & - \\
Polyphenols & + \\
Flavonoids & + \\
Saponins & + \\
Tannins & + \\
Steroids and Terpenoids & + \\
Quinones & + \\
\end{tabular}

compared with other groups. It indicates the absence of healing in the povidone-iodine control group on the seventh day after the wound infliction. The number of cells and the size of the collagen cell in both dose- 1 and dose- 2 treatment groups significantly differed from those of the control groups. Meanwhile, there was no significant difference in the number of cells and collagen cell size between the two dose treatments (Figure 5.D and 5.E). These results indicate that $I$. balsamina extract treatment showed a higher wound healing activity.

\section{Count of inflammatory cells and area of collagen formation}

The number of inflammatory cells and the area of collagen formation is shown in Table 3 . Table 3 shows that the average number of inflammatory cells between the control groups and the two extract dose groups are significantly different. The number of inflammatory cells in both dose-1 and dose-2 group showed are significantly lower than those of all control groups $(p<0.05)$. This suggests that the $I$. balsamina extract is effective in decreasing the amount of tissue inflamed cells. Both dose group treatments resulted in fewer inflammatory cells compared with that of the control group and showed a significant reduction at seventh observation day as shown in Figure 5. Theoretically, the number of inflamed cells will decrease on the seventh day after the wounding (Bayu et al. 2010).

Table 3 also shows that the formation of collagen in dose- 1 and the dose- 2 groups was significantly higher than those of the control groups on day seven. This result suggests that the leaves extract positively affect the formation of collagen. The previous report suggests that the formation of fibroblasts which are collagen-forming cells occurs on the seventh day after injury (Cotran et al. 1999).

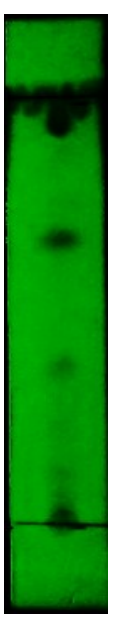

A

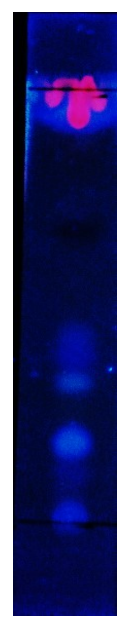

B

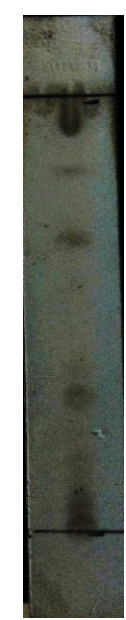

C
Figure 3. The Profile of Thin I ayer Chromatography; A. Under $254 \mathrm{~nm}$ UV light, B. Under $366 \mathrm{~nm}$ UV light, C. $\mathrm{H}_{2} \mathrm{SO}_{4}$-Sprayed plate $\left(10 \% \mathrm{H}_{2} \mathrm{SO}_{4}\right.$ in methanol) Note: $+=$ Chemical compound detected; $=$ Chemical compound indetected 
Table 2. Anatomical pathology observation results

\begin{tabular}{|c|c|c|c|c|c|}
\hline \multirow[t]{2}{*}{ Day } & \multicolumn{5}{|c|}{ Group } \\
\hline & Normal & Negative & Povidone iodine & Dose-1 & Dose-2 \\
\hline 2 & $\begin{array}{l}\text { The wound was wet and its size } \\
\text { became smaller }\end{array}$ & $\begin{array}{l}\text { The wound was wet and became } \\
\text { smaller }\end{array}$ & $\begin{array}{l}\text { The wound was wet and became } \\
\text { smaller }\end{array}$ & $\begin{array}{l}\text { The wound was wet and became } \\
\text { smaller }\end{array}$ & $\begin{array}{l}\text { The wound dried and became } \\
\text { smaller }\end{array}$ \\
\hline 4 & $\begin{array}{l}\text { The wound dried and the wound } \\
\text { size did not change compared to } \\
\text { that of day } 2\end{array}$ & $\begin{array}{l}\text { The wound was dried and the } \\
\text { wound size did not change } \\
\text { compared to that of day } 2\end{array}$ & $\begin{array}{l}\text { The wound dried, scabs were formed } \\
\text { and the wound size did not change } \\
\text { compared to that of day } 2\end{array}$ & $\begin{array}{l}\text { The wound dried and became } \\
\text { compared to that of day } 2\end{array}$ & $\begin{array}{l}\text { The wound dried, scabs were } \\
\text { formed and the wound size } \\
\text { became smaller compared to that } \\
\text { of day } 2\end{array}$ \\
\hline 6 & $\begin{array}{l}\text { The wound dried, scabs were } \\
\text { formed and the wound size did } \\
\text { not change compared to that of } \\
\text { day } 4\end{array}$ & $\begin{array}{l}\text { The wound dried, scabs were } \\
\text { formed and the wound size did not } \\
\text { change compared to that of day } 4\end{array}$ & $\begin{array}{l}\text { The scabs were still attached to the } \\
\text { skin and the wound size did not } \\
\text { change compared to that of day } 4\end{array}$ & $\begin{array}{l}\text { The wound dried, scabs were } \\
\text { formed and the wound size did } \\
\text { not change compared to that of } \\
\text { day } 4\end{array}$ & $\begin{array}{l}\text { The scabs were still attached to } \\
\text { the skin and the wound size did } \\
\text { not change compared to that of } \\
\text { day } 4\end{array}$ \\
\hline 8 & $\begin{array}{l}\text { The scabs were still attached to } \\
\text { the skin and the wound size did } \\
\text { not change compared to that of } \\
\text { day } 6\end{array}$ & $\begin{array}{l}\text { The scabs were still attached to the } \\
\text { skin and the wound size did not } \\
\text { change compared to that of day } 6\end{array}$ & $\begin{array}{l}\text { The scabs were still attached to the } \\
\text { skin and the wound size did not } \\
\text { change compared to that of day } 6\end{array}$ & $\begin{array}{l}\text { The scabs were detached and the } \\
\text { wound size was smaller than } \\
\text { before }\end{array}$ & $\begin{array}{l}\text { The scabs were still attached to } \\
\text { the skin and the wound size did } \\
\text { not change compared to that of } \\
\text { day } 6\end{array}$ \\
\hline 10 & $\begin{array}{l}\text { The scabs were detached, the } \\
\text { wound was wet but smaller than } \\
\text { before }\end{array}$ & $\begin{array}{l}\text { The scabs were still attached to the } \\
\text { skin and the wound size did not } \\
\text { change compared to that of day } 8\end{array}$ & $\begin{array}{l}\text { The scabs were still attached to the } \\
\text { skin and the wound size did not } \\
\text { change compared to that of day } 8\end{array}$ & $\begin{array}{l}\text { The wound dried and its size } \\
\text { became smaller compared to that } \\
\text { of day } 8\end{array}$ & $\begin{array}{l}\text { The scabs were unattached and } \\
\text { the wound was smaller than } \\
\text { before }\end{array}$ \\
\hline 12 & $\begin{array}{l}\text { The wound dried and its size } \\
\text { became smaller compared to that } \\
\text { of day } 10\end{array}$ & $\begin{array}{l}\text { The scabs were still attached to the } \\
\text { skin and the wound size became } \\
\text { smaller compared to that of day } 10\end{array}$ & $\begin{array}{l}\text { The scabs were still attached to the } \\
\text { skin and the wound size did not } \\
\text { change compared to that of day } 10\end{array}$ & $\begin{array}{l}\text { The wound dried and started to } \\
\text { totally healed }\end{array}$ & $\begin{array}{l}\text { The wound dried and its size was } \\
\text { smaller than that of day } 10\end{array}$ \\
\hline 14 & $\begin{array}{l}\text { The wound dried and its size was } \\
\text { smaller than before }\end{array}$ & $\begin{array}{l}\text { The scabs were still attached to the } \\
\text { skin and the wound size did not } \\
\text { change compared to that of day } 12\end{array}$ & $\begin{array}{l}\text { The scabs were detached and the } \\
\text { wound size became smaller } \\
\text { compared to that of day } 12\end{array}$ & The wound almost totally healed & $\begin{array}{l}\text { The wound dried and started to } \\
\text { totally healed }\end{array}$ \\
\hline 15 & $\begin{array}{l}\text { The wound dried and its size was } \\
\text { smaller than before }\end{array}$ & $\begin{array}{l}\text { The scabs were still attached to the } \\
\text { skin and the wound size did not } \\
\text { change compared to that of day } 14\end{array}$ & $\begin{array}{l}\text { The wound dried and its size was } \\
\text { smaller than before }\end{array}$ & The wound totally healed & $\begin{array}{l}\text { The wound dried and started to } \\
\text { totally healed }\end{array}$ \\
\hline
\end{tabular}




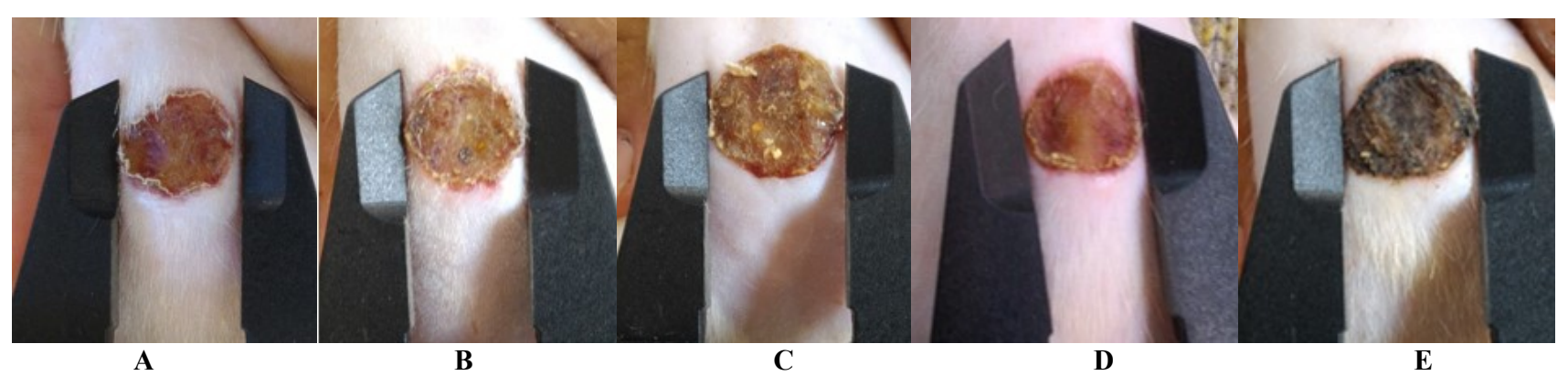

Figure 4. Wound comparison on fifth observation day: A. Normal control group; B. Negative control group; C. Group of Povidone iodine, D. Group of Dose-1; E. Group of Dose-2

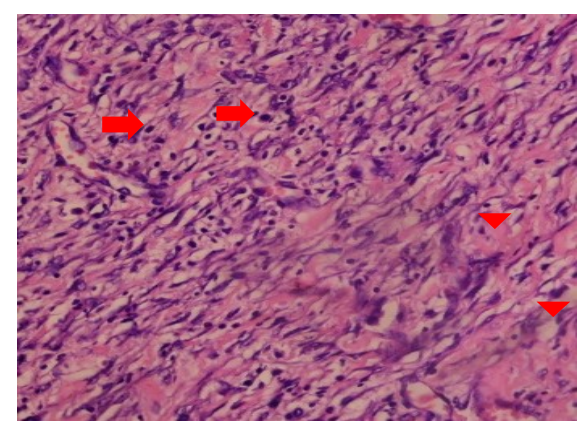

A

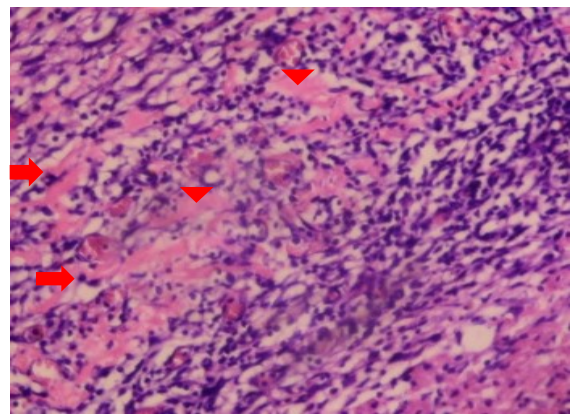

B

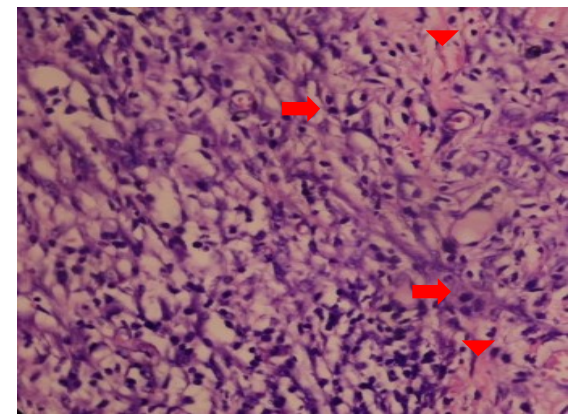

C

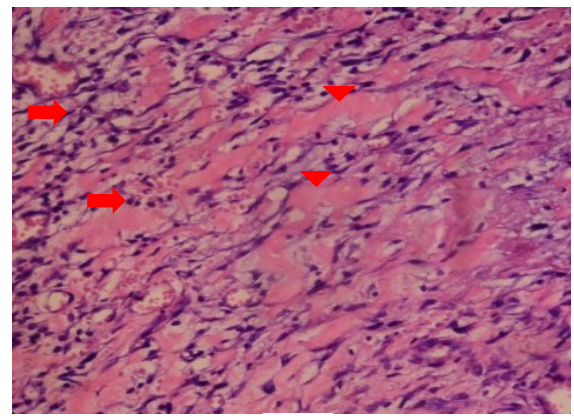

D

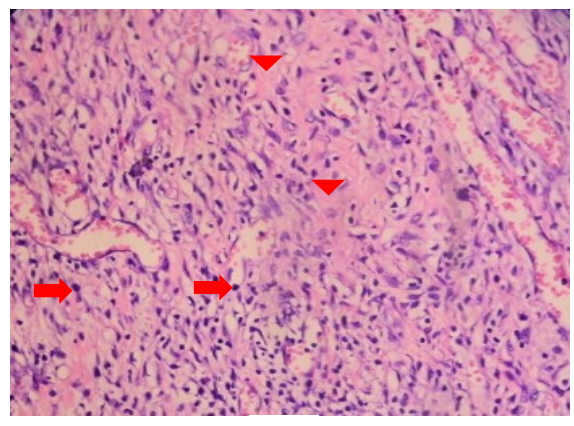

E

Figure 5. Histological observation of rats skin on day 6 under a microscope with 400x magnification: A. Normal control group; B. Negative control group; C. Povidone iodine control group; D. group of Dose-1; E. Group of Dose-2. Note: Inflammation cell ( $\Rightarrow$ ), Collagen tissue $(\nabla)$

Table 3. The average number of inflammatory cells and the extent of the collagen formation on 7 th day

\begin{tabular}{lcc}
\hline Groups & The average number of inflammatory cells & The extent of the collagen formation \\
\hline Normal control & $1858,67 \pm 43,0851^{\$}$ & $1116932,50 \pm 1582,90827^{\$}$ \\
Negative control & $1873,67 \pm 21,0317^{\$}$ & $1120020,75 \pm 3312,80368^{\$}$ \\
Povidone iodine & $2156,33 \pm 29,704 *$ & $714461,25 \pm 274,83279 *$ \\
Dose-1 $(10.5 \mathrm{mg})$ & $1367,67 \pm 7,6376^{*}$ & $1719420,29 \pm 5653,0101^{*}$ \\
Dose-2 $(21 \mathrm{mg})$ & $1380,33 \pm 38,371^{\$}$ & $1722754,21 \pm 1694,4307^{\$}$ \\
\hline
\end{tabular}

Note: $*=(p<0,05)$ significantly different compared to normal control group, $\$=(p<0,05)$ significantly different compared to povidone iodine control group 


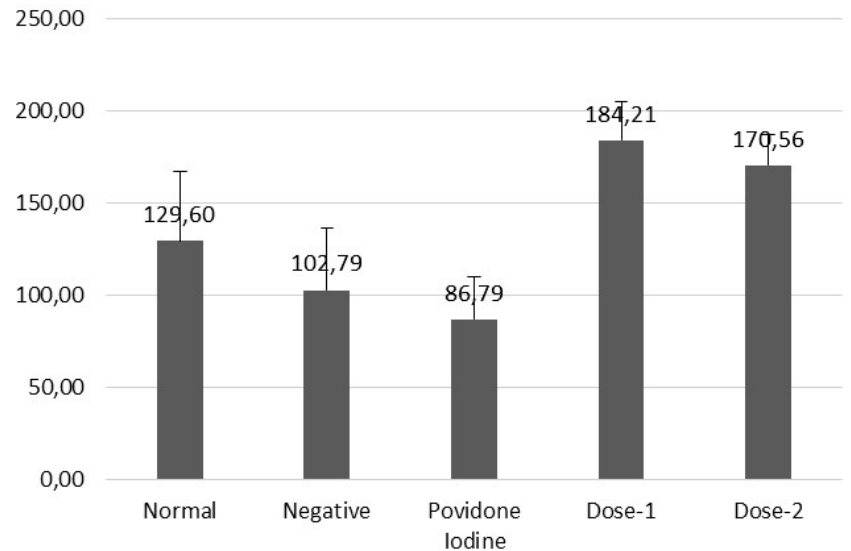

Figure 6. Graph of AUC value wound healing activity

\section{AUC value analysis}

Figure 6 shows the Area Under Curve (AUC) value of each treatment group. The AUC data shows overall healing activity, from the $1^{\text {st }}$ day until the $9^{\text {th }}$ day of observation. The healing activity was determined by the reduced percentage of the wound area each day. Based on the analysis of AUC, we found that the group of dose-1 had a significant difference in AUC values $(p<0.05)$ compared with the group of normal, negative and povidone iodine, but did not show a significant difference $(p>0.05)$ from that of the dose-2 group. Meanwhile, the AUC of the dose2 extract group was only significantly different $(p<0.05)$ than those of the negative and povidone iodine groups. The group with the lowest healing activity was the povidoneiodine group. The animal test of this group formed a scab that causes no change appears in the size of the wound area during the observation. This proves the previous study which state that povidone-iodine did not effectively promote good wound healing, in fact, most studies showed either impaired wound healing, reduced wound strength, or infection. (Kramer SA,1999). A study provides evidence that the use of $10 \%$ povidone-iodine has an inhibitory effect on fibroblast growth in cell culture in vitro (Vogt 2006; Balin and Pratt 2002).

\section{Discussion}

This study was conducted in two steps, the standardization of the I. balsamina leaves ethanol extract and the analysis of the wound healing activity of the extract. Our phytochemical screening result showed that $I$. balsamina leaves extract contained polyphenols, flavonoids, saponins, steroids, terpenoids, tannins, and quinones. This phytochemical screening result and profile of TLC indicate that the ethanol extract which had been used in this study were similar to the I. balsamina extract in the previous study (Hariyanto et al. 2016). This study aimed to determine the wound healing activity of $I$. balsamina leaves extract, especially on a stage 2 wound. The wound was inflicted to the experimental rats by mold and surgical scissors to ensure that the wound only cut the skin until the upper layer of the dermis, approximately 3 $\mathrm{mm}$ from the surface of the rat's skin.
A descriptive and histological observation was conducted to observe the difference in speed of each wound healing stages among the groups. Decreasing of inflammatory cells in the treatment group was alleged to be due to secondary metabolite such as flavonoids, tannin dan quinone. Flavonoids compound in the leaves had antiinflammatory and antimicrobial properties; tannins are known to exhibit antimicrobial activity, and quinones can prevent the bacteria to penetrate the wound (Hariyanto et al. 2016). These active compounds render the inflammation short and boost the discharge of inflammatory cells. Our result indicates that the inflammatory stage in both leaves extract dose groups were shorter in comparison with those of the control groups as shown in table 3 .

The formation of collagen connective tissue in the povidone-iodine control group occurred much slower than those in the other treatment groups. This slow formation in the povidone-iodine control group was thought to be due to the toxicogenetic effects of povidone-iodine on fibroblasts which are cells that produce the collagen connective tissue. The disturbance of fibroblasts results in the expansion of collagen (Niedner 1997), as shown by the formation of thick scabs in the povidone-iodine control group. The largest expansion of collagen connective tissue was observed in both leaves extract dose groups. Collagen tissues that were formed allowed the scabs to more readily detached in both dose groups. Flavonoids compound were thought to have the ability to increase the viability of collagen fibers whereas saponin compounds allegedly improve the ability of TGF- $\beta$ receptors present in fibroblasts which are the growth factors required by fibroblasts to synthesize collagen (Kanzaki et al. 1998; Agarwal et al. 2009). A larger collagen connective tissue also lead to a smoother wound scar on the skin of the rats. Some rats in dose groups even recover from the wound without scars left on them.

Wound area observation results which are represented as AUC value indicates the total healing activity. A larger AUC value indicates a better and faster wound healing process. Based on AUC value analysis, the group showing the biggest AUC value was dose-1 group followed by dose2, normal, negative, and povidone-iodine group, respectively. This result affirmed descriptive and histological observation which shows that active ingredient in the ethanol extract of I. balsamina leaves accelerated wound healing process.

Based on those results, we could conclude that the ethanol extract of I. balsamina leaves can accelerate the wound healing process in white rat as indicated by the low number of inflammatory cells and the high rate of collagen formation on the seventh day compared to the control group. Dosage of the extract which gave the best wound healing effectiveness was $10.5 \mathrm{mg} /$ wound area.

\section{ACKNOWLEDGEMENTS}

We thank Indonesian Ministry of Research, Technology and Higher Education for the financial support for this study through Hibah PEKERTI 2016. 


\section{REFERENCES}

Adfa M. 2006. 6-Metoksi, 7-hidroksi kumarin dari daun pacar air (Impatiens balsamina Linn.). Jurnal Gradien 2 (2): 183-186. [Indonesian]

Adfa M. 2008. Senyawa antibakteri dari daun pacar air (Impatiens balsamina L.). Jurnal Gradien 4 (1): 318-322. [Indonesian]

Agarwal PK, Singh A, Gaurav K, Goel S, Khanna HD, Goel RK. 2009 Evaluation of wound healing activity of extracts of plantain banana (Musa sapientum var. paradisiaca) in rats. Indian J Exp Biol 47: 322 40.

Balin AK, Pratt L. 2002. Dilute povidone-iodine solutions inhibit human skin fibroblast growth. Dermatol Surg 28 (3): 210-214.

Bayu FP, Wientarsih I, Pontjo B. 2010. Aktivitas sediaan salep ekstrak batang pohon pisang ambon (Musa Paradisiaca var Sapientum) dalam proses persembuhan luka pada mencit (Mus Musculus Albinus). Majalah Obat Tradisional 15 (3): 121-137. [Indonesian]

Cotran RS, V. Kumar, T. Collins. 1999. Pathology basic of disease. 6th ed. W.B. Saunders Co, Philadelphia.

Depkes [Departemen Kesehatan] RI. 1994. Inventaris tanaman obat Indonesia. 3rd Ed. Badan Penelitian dan Pengembangan Kesehatan, Jakarta. [Indonesian]

Depkes [Departemen Kesehatan] RI. 1995. Materia Medika Indonesia Vol VI. Departemen Kesehatan RI, Jakarta. [Indonesian]

Harborne AJ. 1998. Phytochemical Methods A Guide to Modern Techniques of Plant Analysis. Springer, Netherlands.

Hariyanto IH, Kusharyanti I, Iwo MI. 2016. Antiarthritic activity of pacar air (Impatiens balsamina Linn.) herb extract in animal model of rheumatoid arthritis-autoimmune disease. Intl J PharmTech Res 9 (3): 131-137.

Kang SN, Goo YM, Yang MR, Ibrahim RI, Cho JH, Kim IS, Lee OH 2013. Antioxidant and antimicrobial activities of ethanol extract from the stem and leaf of Impatiens balsamina L. (Balsaminaceae) at different harvest times. Molecules. 18 (6): 6356-6365.

Kanzaki T, Monsaki N, Shinta R, Saito Y. 1998. Role of transforming growth factor- $\beta$ pathway in the mechanism of wound healing by saponin from Ginseng Radix Rubra. Br J Pharmacol 125: 255-262.

Kramer SA. 1999. Effect of povidone-iodine on wound healing: A review. J Vasc Nurs Mar 17 (1): 17-23.

Kristanti AN, Aminah NS, Tanjung M, Kurniadi B. 2008. Buku Ajar Fitokimia. Airlangga University Press, Surabaya. [Indonesian]

Niedner R. 1997. Cytotoxicity and sensitization of povidone-iodine and other frequently used anti-infective agents. Dermatology 195 (2): 8992.

Oku H, Ishiguro K. 2011. Antipruritic and antidermatitic effect of extract and compounds of Impatiens balsamina L. in atopic dermatitis model NC mice. Phytother Res 15 (6): 506-510.

Robinson T. 1983. The Organic Constituents of Higher Plants Their Chemistry and Interrelationships. 5th ed. Cordus Press, North Amherst.

Vogt PM. 2006. PVP-iodine in hydrosome and hydrogel-a novel concept in wound therapy leads to enhanced epithelialization and reduced loss of skin grafts. Burns 32 (6): 698-705.

Winarsih W, Wientarsih I, Handharyani E, Almira RM. 2010. Evaluasi aktivitas fraksi hexan rimpang kunyit (Curcuma longa) dalam persembuhan luka pada mencit. Hemera Zoa 1 (2): 37-44. [Indonesian] 